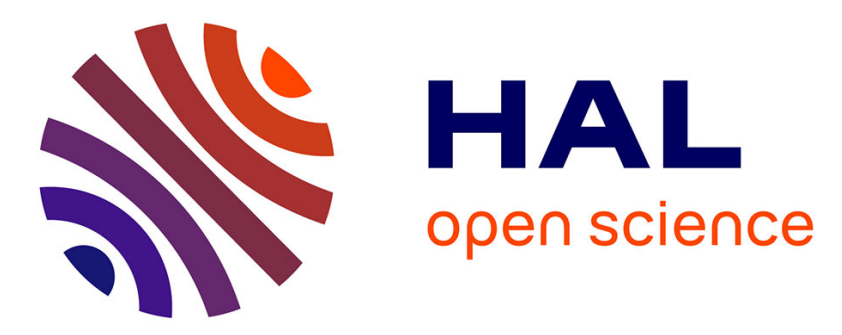

\title{
Dietary shifts in two vultures after the demise of supplementary feeding stations: consequences of the EU sanitary legislation
}

\author{
José A. Donázar, Ainara Cortés-Avizanda, Martina Carrete
}

\section{To cite this version:}

José A. Donázar, Ainara Cortés-Avizanda, Martina Carrete. Dietary shifts in two vultures after the demise of supplementary feeding stations: consequences of the EU sanitary legislation. European Journal of Wildlife Research, 2010, 56 (4), pp.613-621. 10.1007/s10344-009-0358-0 . hal-00551936

\author{
HAL Id: hal-00551936 \\ https://hal.science/hal-00551936
}

Submitted on 5 Jan 2011

HAL is a multi-disciplinary open access archive for the deposit and dissemination of scientific research documents, whether they are published or not. The documents may come from teaching and research institutions in France or abroad, or from public or private research centers.
L'archive ouverte pluridisciplinaire HAL, est destinée au dépôt et à la diffusion de documents scientifiques de niveau recherche, publiés ou non, émanant des établissements d'enseignement et de recherche français ou étrangers, des laboratoires publics ou privés. 


\title{
Dietary shifts in two vultures after the demise of supplementary feeding stations: consequences of the $\mathrm{EU}$ sanitary legislation
}

\author{
José A. Donázar • Ainara Cortés-Avizanda • \\ Martina Carrete
}

Received: 11 September 2009 /Revised: 12 November 2009/Accepted: 4 December 2009 /Published online: 5 January 2010

(C) Springer-Verlag 2009

\begin{abstract}
Among vertebrates, specialization in scavenging has appeared only in "true" Gyps vultures, which usually base their diet almost exclusively on carcasses of medium and large-sized mammals, whereas all other scavengers rely on broader ranges of prey. The availability of food for scavengers in Western Europe has not been limited during recent decades permitting the existence and growth of huge vulture populations. From 2000 onwards, however, EU sanitary legislation has progressively limited the abandonment of dead animals in the field resulting in a sudden reduction of food availability with unknown ecological and conservation consequences. Here, we examine the dietary response of a tandem of carrion eaters, the griffon vulture (Gyps fulvus) and the Egyptian vulture (Neophron percnopterus), showing different degrees of dietary specialization. Our results showed that after the reduction in numbers of supplementary feeding stations (vulture restaurants) the niche breadth of the griffon vulture has broadened and now includes significant amounts of wild rabbits (Oryctolagus cuniculus) and garbage. The diet of the Egyptian vulture, on the contrary, did not vary substantially. The diet overlap showed patterns probably conditioned by interspecific competition and the progressive exploitation of unpredictable carcasses. On a short-term scale, consequences for smaller scavengers could be negative due to the monopolization of resources by the dominant and much more abundant griffon vulture, however in the long-term all guild
\end{abstract}

Communicated by C. Gortázar

J. A. Donázar $(\bowtie) \cdot A$. Cortés-Avizanda $\cdot$ M. Carrete

Department of Conservation Biology,

Estación Biológica de Doñana, CSIC,

c/. Américo Vespucio s/n, Isla de la Cartuja,

41092 Sevilla, Spain

e-mail: donazar@ebd.csic.es species would benefit from the exploitation of unpredictable carcasses, which could enhance the possibilities of coexistence.

Keywords Diet · EU sanitary legislation - Egyptian vulture . Griffon vulture $\cdot$ Spain $\cdot$ Supplementary feeding

\section{Introduction}

Coexistence of species exploiting the same resource is facilitated by heterogeneous environments, which allow differential use of patches with variable environmental features and resource availability (Brown et al. 1994; Wauters et al. 2002; Carrete et al. 2005; Stephens et al. 2007). Within those guilds embracing species having carnivore food habits, the diversity of the diet may be also based mainly on the variability in size of the prey (Begon et al. 2006). In the case of carrion-eater guilds, the degree of sharing of common resources (carcasses) depends on morphological and behavioral traits (Mundy et al. 1992; Hertel 1994; Hertel and Lehman 1998). Thus, in each geographical region, there is one or two species of "true" scavengers ("Gyps" vultures and some Cathartidae in the Old and New World, respectively); their morphological adaptations and their social behavior allow these vultures to specialize in the consumption of large carcasses (Houston 1983; König 1983; Wallace and Temple 1987). On the contrary, other scavengers are more polyphagous and, although they also exploit large carcasses, they invariably consume a number of small and medium-sized prey (Hiraldo et al. 1991a; Mundy et al. 1992; Travaini et al. 1998). When several species concur at the same carcass, coexistence is made possible on the basis of resource partitioning, involving facilitatory and competitive processes 
still not well understood and apparently dependent on constraints linked to the species' life-history strategies and local conditions inherent to each carcass (Kruuk 1967; Wallace and Temple 1987; Mundy et al. 1992; Margalida et al. 2009). Facing scarce resources, competitive displacement may appear to permit the monopolization of the food source by the most aggressive (and eventually abundant) species (Hiraldo et al. 1991b).

Given the scenario of a global vulture crisis (Koenig 2006), it is remarkable that the Iberian Peninsula and in particular, Spain, still holds the largest populations of avian scavengers in Europe and probably in the Old World (BirdLife International 2008; Margalida et al. 2009). This is the result of both legal protection and high food availability. During the second half of the 20th century, food availability was well above that required to maintain the scavenger populations leading to a spectacular increase in population size, especially that of the griffon vulture (around 500\% between 1979 and 1999; Donázar and Fernández 1990; Parra and Tellería 2004; Del Moral and Martí 2001). This situation was exacerbated by a failure to comply with sanitation laws enforced since the 1950s which forbade the abandonment of carcasses in the field (Donázar et al. 2009a). In 1999, bovine spongiform encephalopathies (BSEs) brought about strict EU legislation aimed at the elimination of animal by-products (Tella 2001). As a consequence, state and regional administrations reinforced measures requiring farmers to remove or destroy the remains of dead livestock (Donázar et al. 2009a). Such laws were implemented from 2000 onwards but they have been much more strongly enforced since 2005. Consequently, after decades of high food availability for scavengers, there was a sudden decrease in the number of carcasses abandoned by farmers both in the field and in supplementary feeding stations "vulture restaurants" (see Camiña and Montelío 2006; Donázar et al. 2009a). Further EU regulations have allowed the possibility of maintaining some feeding stations aimed to conserve vulture populations, but the number of these places and the amount of food supplied are still very low in relation to population size.

In our study, we examined the impact of recent shortterm changes in the abundance and distribution of resources in a system with two scavenger species: the griffon vulture (Gyps fulvus) and the Egyptian vulture (Neophron percnopterus). Both are members of the same scavenger guild but present a clear trophic segregation (König 1983). The griffon vulture is a large (ca. 10,000 g) specialist whose diet is based on medium and large-sized ungulate carcasses whereas the Egyptian vulture (ca. 2,000 g), although also exploiting large carcasses, consumes high frequencies of small and medium-sized vertebrates, and garbage (see Donázar 1993; BirdLife International 2008). We hypothesized that the progressive disappearance of food resources linked to large ungulate carcasses (swine, sheep) has provoked asymmetric changes in the diet of the two scavengers. Specifically, we predicted that the trophic specialization of the griffon vulture would lead to few changes in its diet following the decrease in food availability; on the contrary, the Egyptian vulture would respond according to these variations, increasing the consumption of alternative prey.

\section{Materials and methods}

Study area

Our study was carried out between 2005 and 2008 in Navarre and Aragón, Northern Spain (Fig. 1). This region is characterized by a relatively abrupt relief $(300-1,500 \mathrm{~m}$ in altitude) and variable climate $(300-800 \mathrm{~mm}$ of annual precipitation). The landscape is mostly dominated by agriculture (cereals, irrigated fields) and pasturelands with some forests occupying slopes and mountains (see Donázar et al. 1996a for more details). The breeding populations of griffon and Egyptian vultures were estimated in 2004 at around 2,400 and 380 pairs, respectively. In 2005, there were around 250 feeding stations or "vulture restaurants" established at which dead animals were regularly disposed for consumption by avian scavengers. Most of these feeding stations were associated with intensive swine farms and, to a lesser extent, sheep raising. Although the closing of the feeding stations began in the study area prior to 2005 (Camiña and Montelío 2006), the main quantitative change took place after this date. Thus, during the spring and summer of 2007, following EU legislation, most of the feeding stations in Aragón (western study area) were closed. During the autumn and winter of 2007, similar measures were taken in Navarra (eastern study area). Currently, large carcasses are only available in some feeding places (less than 25 in the entire study area). Apart from this, some owners of either extensive operations in remote areas (mountains) or small intensive farms continue to abandon carcasses in the field though these are minimal in comparison to those that existed before the EU legislation. Overall, it has been estimated that more than $80 \%$ of the formerly existing supplementary feeding stations were closed in the study area between 2007 and 2008; thus, only a third of the requirements of the vulture populations would be covered by the remnant vulture restaurants (Donázar et al. 2009a; Regional Governments, unpublished data).

Field procedures

Pellet collection was carried out in communal roosts existing in an area of around $5,000 \mathrm{~km}^{2}$ located around 
Fig. 1 Study area (Ebro Valley, N. Spain) showing the four studied roosting areas (A-D griffon vulture: inverted triangle; Egyptian vulture: triangle). Main predictable sources of food in the surroundings: rubbish dumps: squares, supplementary feeding stations: circles; open circles represent feeding stations closed during the study period

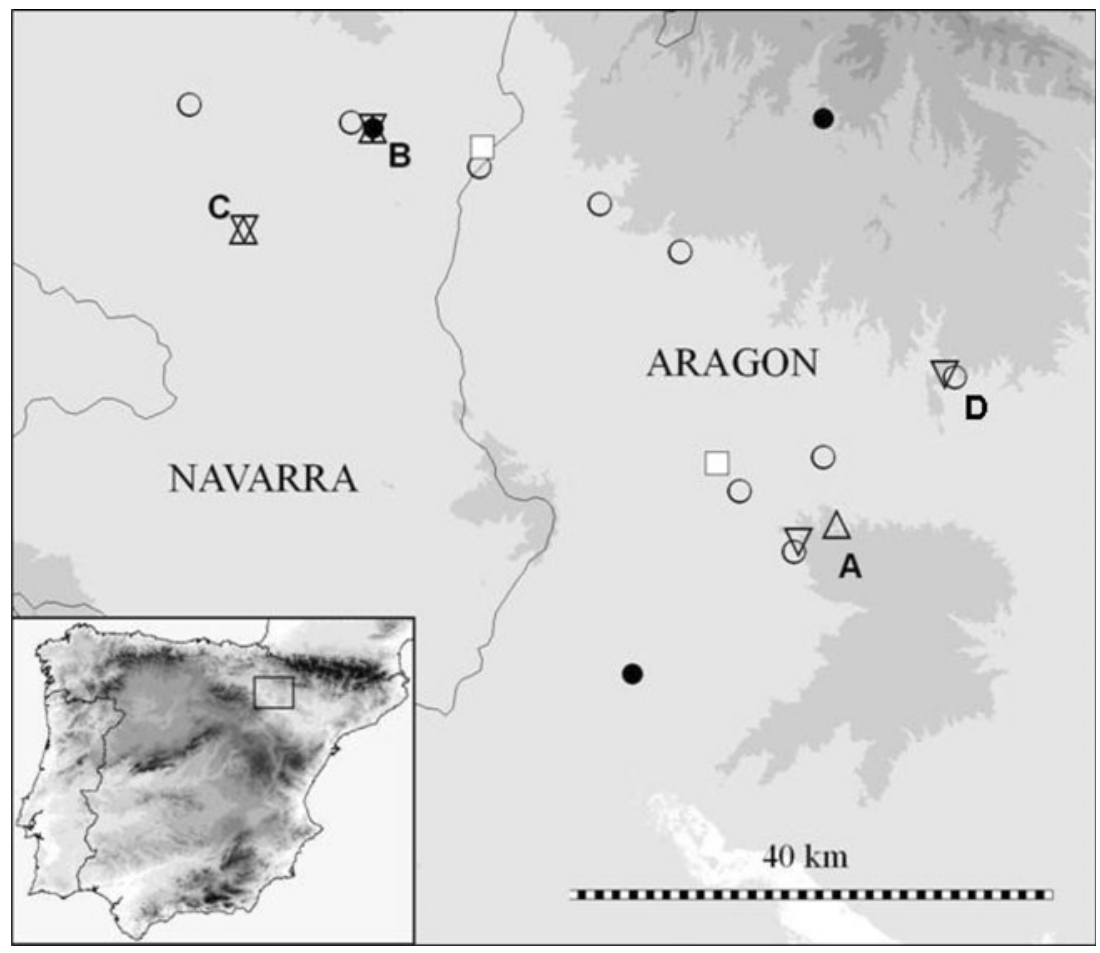

Ejea de los Caballeros (420750N, 10820W, Ebro valley; Fig. 1). During the summers (July-August) of 2005, 2007, and 2008 we collected pellets of griffon vultures in four communal roosts. They were located in cliffs and trees on abrupt slopes. During the same period, we also collected pellets of Egyptian vultures in three communal roosts placed in woody areas. Two of these roosts (A and B) were associated with predictable food resources (intensive farm areas and garbage dumps) and the third (C) was in an area with high densities of wild rabbit (Oryctolagus cuniculus) and extensive sheep farming; immature and adult birds were observed regularly in all these roosts (see Donázar et al. 1996a for more details). Three of the roosts (A, B, and C) were shared by the two studied species, however, within roosts, well-separated places were used for perching which permitted us to identify the species that had cast the pellet. Because all the samples were collected at the end of the breeding season, our data samples can be considered as representative of the food habits of these scavengers during the summer (last part of the reproductive period, when the main roost are formed, Donázar et al. 1996a). It should be noted that the population of griffon vultures is sedentary whereas the Egyptian vulture has migratory habits, arriving in March and leaving the region in September (Donázar 1993).

The pellets were collected on a single day in each location and all were fresh and/or not dismembered. Hence, it can be inferred that pellets were deposited in the weeks prior to the collection. All the vulture roosts were monospecific, known from observations done during longterm monitoring of these populations (see e.g., Donázar et al. 1996a; Grande 2006; Cortés-Avizanda et al. 2009). Hair, bone, feathers, and scales were used to identify prey remains by comparison to a reference collection. For the griffon vulture and with the purposes of diet quantification, we considered the following prey categories: wild rabbits, sheep (Ovis aries), swine (Sus scrofa), undetermined ungulate (Bovidae, Equidae, and Cervidae), carnivores (Carnivora), poultry (Gallus gallus), and garbage (indicated by the presence of plastic, glass, etc.). For the Egyptian vulture, we considered the same categories and, in addition: rodents (Rodentia); undetermined birds (Aves), insects (Coleoptera), and maggots (Diptera; corresponding to carrion-eater species and not related to pellet decomposition). As is habitual in scavenger diet studies and because bones rarely appeared in pellets, we did not calculate minimum numbers. Alternatively, we estimated the frequency of occurrence of each prey species (percentage of the total number of pellets in which the prey was detected) (see e.g., Hiraldo et al. 1991b; Lambertucci et al. 2009). Although pellet analyses may present some biases (in particular due to the underestimation of items with soft tissues) it is a valid procedure to compare diets of species having parallel food habits as is the case of scavengers (see Hiraldo et al. 1991b; Kelly et al. 2007, and references therein). 
Analytical procedures

We examined the changes in diet composition of griffon and Egyptian vultures during three periods:

1. Year 2005, when the availability of feeding stations was high.

2. Year 2007, after the closing of the feeding stations located in the eastern study area (Aragón).

3. Year 2008, after the closing of the last remaining feeding stations, located in the western study area (Navarra).

We used Generalized Linear Models (GLM; McCullagh and Nelder 1989; link function, logit; error distribution, binomial) to detect interannual changes in the probability of occurrence of each prey category in the diet of griffon vultures. We considered each pellet as a simple unit and the presence/absence $(1 / 0)$ of each prey as a response variable (link function, logit; error distribution, binomial). The year was considered an explanatory continuous variable reflecting the continuous decrease in the availability of food resources during the study period. Because the range of movements of griffon vultures (up to $75 \mathrm{~km}$; Donázar 1993) clearly exceeds the distance between the studied roosts (maximum $60 \mathrm{~km}$ ) we did not consider them as independent sampling zones.

For the Egyptian vulture, we used Generalized Linear Mixed Models (GLMM; McCullagh and Searle 2000). It is well-known that Egyptian vulture roosts are associated with food sources and that the same individuals frequently remain attached to the same roosts for periods of days or weeks (Donázar et al. 1996a; authors personal observation). In addition, the range of movements of individuals is usually below $15 \mathrm{~km}$ (Donázar 1993; authors unpublished). For these reasons, to control for potential variability among roosts as well as to avoid non-independence of the data, we fixed in models the roost as a random term. Response and explanatory variables were similar to those considered in the analyses for griffon vultures.

Following Mysterud (2000), niche breadth (B) was calculated on the basis of the Shannon-Wiener information measure (Hanski 1978): $B_{\mathrm{j}}=-\Sigma_{\mathrm{j}} p_{\mathrm{ij}} \ln \left(p_{\mathrm{ij}}\right)$. The overlap in diet $\left(O_{\text {ge }}\right)$ between griffon $(g)$ and Egyptian vultures $(e)$, was calculated with the Schoener's index (Schoener 1968): $O_{\text {ge }}=1-1 / 2 \Sigma\left|p_{\text {ig }}-p_{\text {ie }}\right|$, where $p_{\text {ig }}$ and $p_{\text {ie }}$ were the proportions of the prey category $i$ in the diet of the griffon and the Egyptian vulture, respectively. Overlap varies between 0 (absent) to 1 (complete).

\section{Results}

We analyzed 844 pellets (griffon vulture, 403; Egyptian vulture, 441) throughout the study area. The number of pellets collected in each roost and year varied from 20 to 70 $(m e a n=44)$ for the griffon vulture and from 9 to 81 (mean= 48 ) for the Egyptian vulture. The frequencies of occurrence of wild rabbit, poultry, and garbage showed a significant increase in the diet of the griffon vulture during the study period (respectively, $\chi^{2}=8.51, p=0.003 ; \chi^{2}=8.24$, $p=0.004 ; \chi^{2}=7.89, p=0.005$; Fig. 2). In 2008, wild rabbits occurred in almost $10 \%$ of the pellets (Fig. 2, Appendix 1). The frequency of swine showed the opposite trend $\left(\chi^{2}=9.77, p=0.002\right.$; Fig. 2$)$ in parallel with the closing of the main feeding stations (Fig. 2). Only poultry varied significantly within the Egyptian vulture's diet, decreasing during the study period $\left(F_{1,428}=33.45, p<0.0001\right.$; Fig. 2$)$. Wild rabbits did not show significant variations with frequencies close to $20 \%$ (Fig. 2).
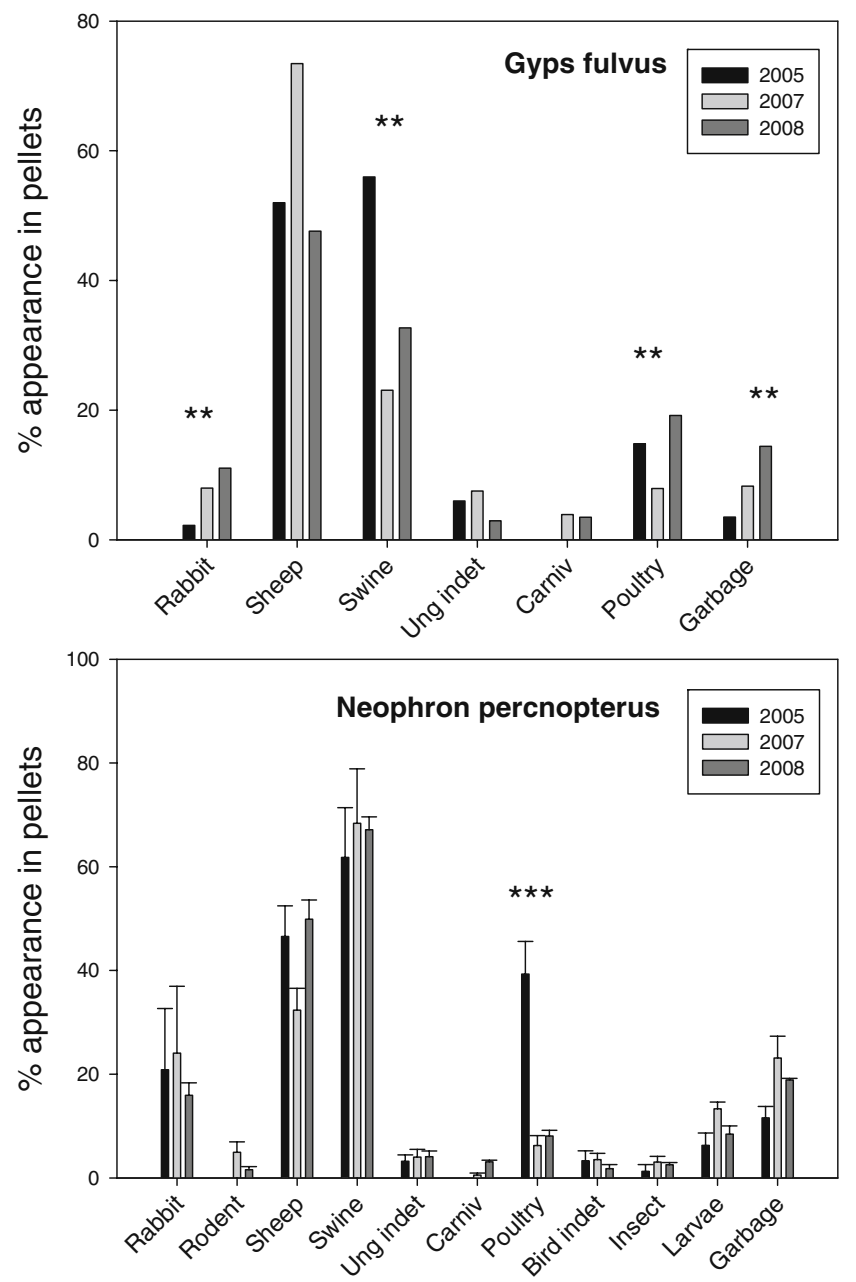

Fig. 2 Variations in the food habits of the griffon and Egyptian vultures along the study period: $<2007$ : prior to the closure of feeding stations; 2007: During the closure; 2008: after the closure. For the griffon vulture and because pellets collected in the same year were considered as a single sample total values are shown (without error bars). For the Egyptian vulture we considered separately the samples collected in each communal roost; annual mean values and standard errors are shown. Differences between periods were estimated on the basis of modeling procedures (see "Materials and methods"): $* * p<0.01 ; * * * p<0.001$ 
Niche breadth of both species increased progressively during the study period (Table 1) although the differences between periods, considering each roost independently, did not reach significance in the case of the Egyptian vulture (Kruskal-Wallis test, $p=0.281$ ). Diet overlap between the two species revealed divergent results in relation to each Egyptian vulture roost (Table 2). During the study period, griffon vultures showed a growing overlap with those Egyptian vultures roosting in areas where resources were unpredictable (roost C). Overlap with Egyptian vultures depending on predictable resources (vulture restaurants and rubbish dumps; roosts $\mathrm{A}$ and $\mathrm{B}$ ) was similar during the first and last part of the study period and showed minimum values during 2007, when some of the feeding stations had been closed (Fig. 3).

\section{Discussion}

Our results, contrary to those predicted, showed that the decline in food availability due to EU regulations prohibiting the disposal of carcasses in the field has triggered significant changes in the diet composition of the griffon vulture. After the closing of most feeding stations it has begun to consume significant numbers of small vertebrates increasing its niche breadth. Carnivores show a preference for items rewarding higher benefits (Begon et al. 2006). When the diet is extremely specialized, however, these changes are not expected and the preferred prey would be consumed independent of the abundance of alternative items (see Pyke et al. 1977; Stephens et al. 2007). Gyps vultures are specialists exploiting large carcasses having evolved in fluctuating environments where carcass availability was dependent on the displacement of large migratory ungulates. Large body size and soaring flight strategies permit these species to search for food in extremely large regions thus buffering the effects of weather and herd displacements (Houston 1983). Concordantly, all studies carried out on the diet of the griffon

Table 1 Changes in the niche breadth (Shannon-Wiener index) of the griffon and Egyptian vultures in the three considered study periods: 2005: prior to the closure of feeding stations; 2007: during the closure; 2008: after the closure

\begin{tabular}{lllll}
\hline & $\begin{array}{l}\text { Griffon } \\
\text { vulture }\end{array}$ & $\begin{array}{l}\text { Egyptian v. } \\
\text { roost A }\end{array}$ & $\begin{array}{l}\text { Egyptian v. } \\
\text { roost B }\end{array}$ & $\begin{array}{l}\text { Egyptian v. } \\
\text { roost C }\end{array}$ \\
\hline 2005 & 1.27 & 1.69 & 1.57 & 1.79 \\
2007 & 1.47 & 1.64 & 1.65 & 1.92 \\
2008 & 1.64 & 1.71 & 1.77 & 1.76 \\
\hline
\end{tabular}

In the roosts $\mathrm{A}$ and $\mathrm{B}$, the diet of the Egyptian vultures relied mainly on large ungulate carcasses and garbage; in the roost $\mathrm{C}$, wild rabbit was the main prey
Table 2 Change in the overlap (Schoener Index) between the diet of the griffon vulture and the diet of the Egyptian vulture in three communal roosts

\begin{tabular}{llll}
\hline & $\begin{array}{l}\text { Egyptian v. } \\
\text { roost A }\end{array}$ & $\begin{array}{l}\text { Egyptian v. } \\
\text { roost B }\end{array}$ & $\begin{array}{l}\text { Egyptian v. } \\
\text { roost C }\end{array}$ \\
\hline 2005 & 0.77 & 0.81 & 0.51 \\
2007 & 0.43 & 0.53 & 0.53 \\
2008 & 0.73 & 0.78 & 0.63 \\
\hline
\end{tabular}

Three periods have been distinguished: 2005: prior to the closure of feeding stations; 2007: during the closure; 2008: after the closure. In the roosts A and B, the diet of the Egyptian vultures relied mainly on large ungulate carcasses and garbage; in the roost $\mathrm{C}$, wild rabbit was the main prey

vulture in western Europe and other Old World regions show higher and almost exclusive consumption of medium and large-body size vertebrate (mainly ungulate) carcasses such as cow, horses, deer, swine, sheep and goats (Fernández 1975; Elosegi 1989; Mundy et al. 1992; but see Margalida 1997). Consequently, our results show an unusual and unexpected phenomenon probably linked to extreme food conditions with very low availability of food in relation to the size of the griffon vulture population.

Other carnivores with opportunistic diets can reduce the consumption of key prey items when they become less profitable than alternative prey (Glasser 1982). However, the Egyptian vulture in northern Spain has not shown such trends in parallel to the closing of the main feeding stations. In fact, it appears to currently exploit the same prey and in similar proportions to that reported two decades ago in the same study area (wild rabbit, 4-42\%; swine, $8-47 \%$; sheep, 20-73\%; poultry, 10-95\%; garbage, 2-51\%; Ceballos and Donázar 1990). Most likely, other environmental factors determine a very high variability in the diet of this opportunistic feeder, thus masking the effects of the closing of the feeding stations. In fact, we found important differences in the diet between roosts probably because the primary food source is variable (wild rabbits in one case, and ungulate carcasses and garbage in the other two studied cases). Moreover, the large population decline in wild rabbits in the study area during the last decade was caused by rabbit haemorrhagic disease (Villafuerte et al. 1995) may also have contributed to the observed variability since rabbit populations have recovered only partially, showing important spatial variations in density (Calvete et al. 2006).

Trends in food habits of the two species are considered on a broader scale, our results strongly suggest close interdependence and reflect a scenario of interspecific exploitation competition (Tokeshi 1999), in this case determined by different body size (Cody and Diamond 

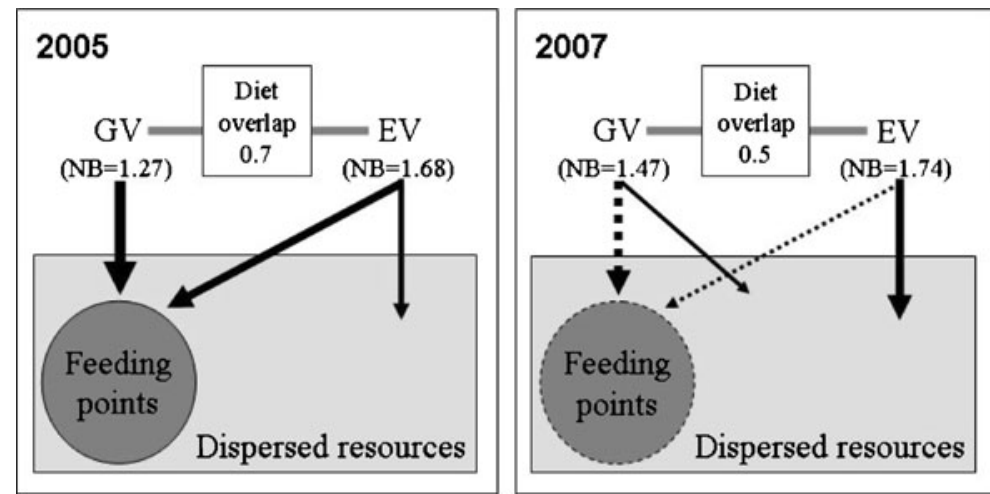

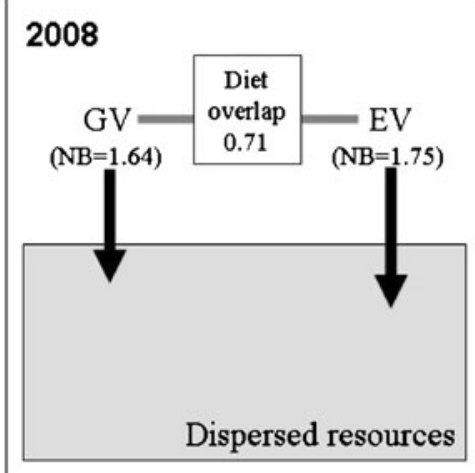

Fig. 3 Conceptual model explaining the observed changes in the diet overlap between griffon $(G v)$ and Egyptian vultures $(E v)$ according to results obtained in this study. In 2005, supplementary feeding stations and unpredictable sources of food were available; both vultures fed mainly at feeding stations (high overlap). In 2007, the number of feeding stations decreased, and could have been monopolized by griffon vultures which also would begin to exploit unpredictable resources which were also heavily exploited by Egyptian vultures (low overlap). In 2008, most of the feeding stations disappeared and the two vultures relied mainly on unpredictable sources of food (high overlap)

marked not only by a lower trophic carrying capacity but also by the more unpredictable spatial distribution of resources. In the short-term, changes are expected in the spatial structure of the population not attached to breeding places. There is also evidence that immature vultures are not longer concentrating in those regions in which abundant and predictable food resources are becoming scarce (Camiña and Montelío 2006). From a long-term perspective, the demographic regulation of the griffon vulture population can be expected on the basis of the new environmental carrying capacity. During recent years (2006-2008) the number of individuals found dead or starving has increased dramatically in the Iberian Peninsula. Moreover, in 2007 and 2008 the breeding success of griffon vultures dropped consistently in populations of northern Spain depending heavily on carcasses from intensive farming (see reviews in Donázar et al. 2009a). Consequently, it can be predicted that the growth of Iberian griffon vulture populations could end in the shortterm and even begin to decline in the long-term. Breeding counts carried out in northern Spain during 2007 and 2008 indicate this trend (Margalida et al. 2009).

Interspecific relationships could also be strongly affected by this new scenario. The scarcity of the main food resources exploited by the griffon vultures (predictable large carcasses) would lead to an increase in indirect competition with subordinate species for small and medium-sized carcasses, in a process similar to the hyperpredation observed in predator-prey systems (Courchamp et al. 2000). In the Iberian Peninsula the carcasses of wild rabbits are heavily exploited by facultative predators and carrion-eaters (Delibes-Mateos et al. 2008) and for some threatened species like the Egyptian vulture, the cinereous vulture (Aegypius monachus) and the bearded vulture (Gypaetus barbatus) 
constitute an essential part of the diet during the breeding period (Hiraldo 1976; Donázar and Ceballos 1988; Margalida et al. 2009). In a field experiment carried out during 2005 and 2006, when the availability of large carcasses was still high, we observed that $30 \%$ of the wild rabbit carcasses were consumed by griffon vultures, which displaced other species like Egyptian vultures, red kites (Milvus milvus), black kites (Milvus migrans), marh harriers (Circus aeruginosus), common European buzzards (Buteo buteo), and common ravens (Corvus corax). In addition, food sources like garbage dumps that until now have been exploited exclusively by opportunistic scavengers (Donázar 1992) can now be monopolized, at least partially, by griffon vultures. Apart of this, the growing consumption of garbage may have serious consequences for the populations of these species because it increases the probability of ingestion of toxic substances (Houston et al. 2007).

In conclusion, the implementation of recent EU legislation is directly affecting the availability of food for the specialist avian scavengers but could also be modifying the trophic relationships within the guild. From a long-term perspective, the structure and functioning of the guild could be highly dependent on the regulation of the griffon vulture population given the new availability and spatial distribution of resources. Even if, in the short-term, negative consequences for populations of more threatened scavengers such as the Egyptian vulture are expected, in the long-term the situation could improve the conservation outlook because all the species would depend on more unpredictable resources. In the end, this scenario would be more similar to those in which the foraging strategies of avian scavengers evolved. Moreover, there would be fewer incidences of other negative factors threatening the populations of carrion eaters depending on intensive livestock such as the ingestion of veterinary drugs and pathogen transmission (Blanco et al. 2007; Lemus et al. 2008). Also, a higher availability of carcasses would reduce the probability of ingestion of poisoned preys (Margalida et al. 2008). It is necessary for EU legislation and the regulation of the states and regions to have enough flexibility to authorize owners of extensive operations to abandon the carcasses of their livestock in order to sustain populations of avian scavengers (Donázar et al. 2009b).

Acknowledgements Funding during a part of this study came from Viveros y Repoblaciones de Navarra S.A. (Navarre Government). The remainder support has been provided by the Project CGL200400270/BOS. MC was supported by a Juan de la Cierva postdoctoral contract. We thank N. Markina, and M. Rodriguez for their help during fieldwork. O. Ceballos, A. Margalida and two anonymous reviewers made helpful comments on earlier versions of the manuscript.

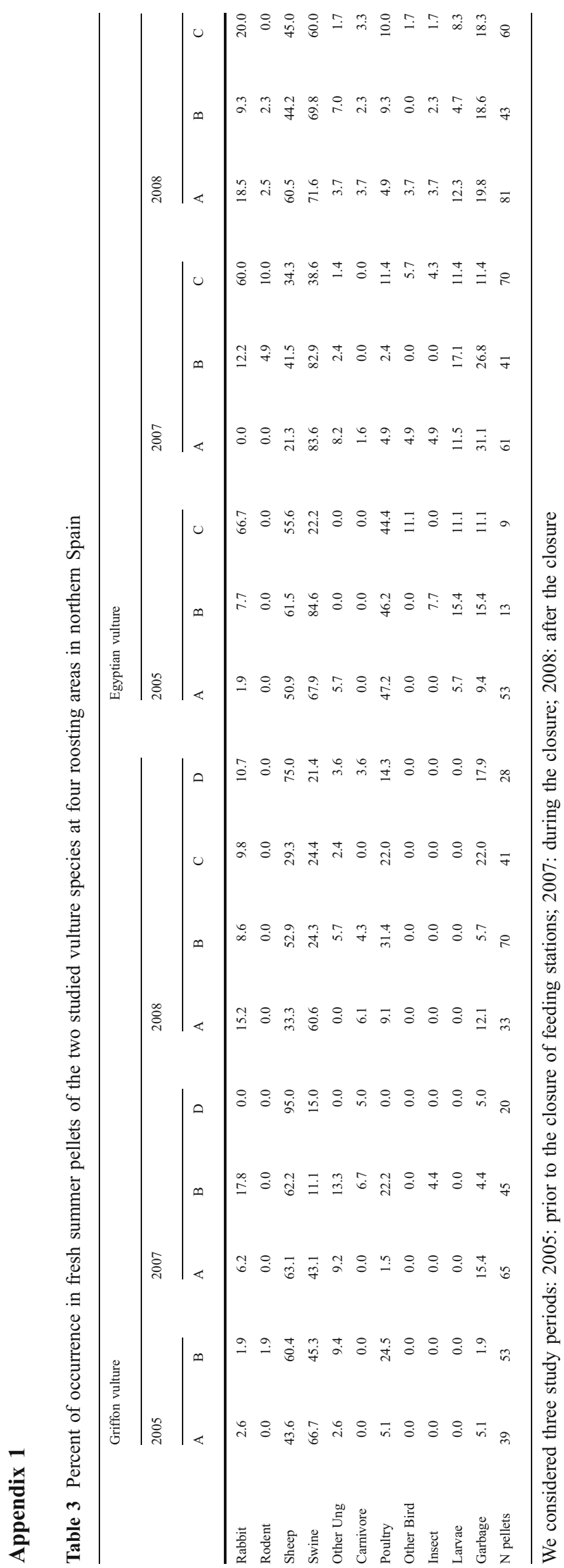




\section{References}

Begon M, Townsend CR, Harper JL (2006) Ecology: from individuals to ecosystems, 4th edn. Wiley-Blackwell, Malden

BirdLife International (2008) Action Plan for the Egyptian Vulture Neophron percnopterus in the European Union

Blanco G, Lemus JA, Grande J, Gangoso L, Grande M, Donázar JA, Arroyo B, Frías O, Hiraldo F (2007) Geographical variation in cloacal microflora and bacterial antibiotic resistance in a threatened avian scavenger in relation to diet and livestock farming practices. Environ Microbiol 9:1738-1749

Brown JS, Kotler BP, Mitchell WA (1994) Foraging theory, patch use, and the structure of a Negev Desert granivore community. Ecology 75:2286-2300

Calvete C, Pelayo E, Sampietro J (2006) Habitat factors related to wild rabbit population trends after the initial impact of rabbit haemorrhagic disease. Wildl Res 33:467-474

Camiña A, Montelío E (2006) Griffon vulture Gyps fulvus food shortage in the Ebro Valley (NE Spain) caused by regulations against Bovine Spongiform Encephalopathy (BSE). Acta Ornithol 41:3-17

Carrete M, Sánchez-Zapata JA, Calvo JF, Lande R (2005) Demography and habitat availability in territorial occupancy of two competing species. Oikos 108:125-136

Ceballos O, Donázar JA (1990) Roost-tree characteristics, food habits and seasonal abundance of roosting EgyptianVultures in Northern Spain. J Raptor Res 24:19-25

Cody ML, Diamond D (1975) Ecology and evolution of communities. Harvard University Press, Cambridge

Cortés-Avizanda A, Ceballos O, Donázar JA (2009) Long-term trends (1989-2007) in population size and breeding success in the Egyptian vulture (Neophron percnopterus) in northern Spain. J Raptor Res 43:43-49

Courchamp F, Langlais M, Sugihara G (2000) Rabbits killing birds: modelling the hyperpredation process. J Anim Ecol 69:154-164

Delibes-Mateos M, Delibes M, Ferreras P, Villafuerte R (2008) Key role of European rabbits in the conservation of the western Mediterranean Basin hotspot. Cons Biol 22:1106-1117

Del Moral JC, Martí R (2001) El Buitre leonado en la Península ibérica. Monografía $n^{\circ}$ 7. SEO/BidLife. Madrid

Donázar JA (1992) Muladares y basureros en la biología y conservación de las aves en España. Ardeola 39:29-40

Donázar JA (1993) Los buitres ibéricos. J.M. Reyero Editor, Madrid

Donázar JA, Ceballos O (1988) Alimentación y tasas reproductoras del Alimoche (Neophron percnopterus) en Navarra. Ardeola 35:3-14

Donázar JA, Fernández C (1990) Population trends of Griffon Vultures (Gyps fulvus) in northern Spain between 1969 and 1989 in relation to conservation measures. Biol Cons 53:83-91

Donázar JA, Ceballos O, Tella JL (1996a) Communal roost of Egyptian vultures (Neophron percnopterus): dynamics and implications for the species conservation. In: Muntaner J, Mayol $\mathrm{J}$ (eds) Biology and Conservation of Mediterranean Raptors. SEO/BirdLife, Monography 4, Madrid, pp 189-202

Donázar JA, Naveso MA, Tella JL, Campión D (1996b) Extensive grazing and raptors in Spain. In: Pain D, Pienkowski MW (eds) Bird conservation and farming policy in Europe. Academic Press, San Diego, pp 117-149

Donázar JA, Margalida A, Campión D (eds) (2009a) Vultures, Feeding Stations and Sanitary Legislation: A Conflict and Its Consequences from the Perspective of Conservation Biology. Munibe 29 (suppl.), Sociedad de Ciencias Aranzadi, Donostia, Spain

Donázar JA, Margalida A, Carrete A, Sánchez-Zapata JA (2009b) Too sanitary for vultures. Science 326:664
Elosegi I (1989) Vautour fauve (Gyps fulvus), Gypaète barbu (Gypaetus barbatus), Percnoptère d'Egypte (Neophron percnopterus): Synthèse Bibliographique et Reserches. Acta Biologica Montana. Série Documents de Travail 3

Fernández JA (1975) Consideraciones sobre el régimen alimenticio de Gyps fulvus. Ardeola 21:209-217

Glasser JW (1982) A theory of trophic strategies: the evolution of facultative specialists. Am Nat 119:250-262

Grande JM (2006) Factores limitantes, antrópicos y naturales, de poblaciones de aves carroñeras: el caso del alimoche (Neophron percnopterus) en el valle del Ebro. Ph. D. Dissertation, University of Sevilla

Hanski I (1978) Some comments on the measurement of niche metrics. Ecology 59:168-174

Hertel F (1994) Diversity in body size and feeding morphology within past and present vulture assemblages. Ecology 75:1074-1084

Hertel F, Lehman N (1998) A randomized nearest-neighbor approach for assessment of character displacement: the vulture guild as a model. J Theor Biol 190:51-61

Hiraldo F (1976) Diet of the Black Vulture (Aegypius monachus) in the Iberian peninsula. Doñana Acta Vert 3:19-31

Hiraldo F, Blanco JC, Bustamante J (1991a) Unspecialized exploitation of small carcasses by birds. Bird Study 38:200-207

Hiraldo F, Delibes M, Donázar JA (1991b) Comparison of diets of Turkey Vultures in three regions of Northern Mexico. J Field Ornithol 62:319-324

Houston DC (1983) The adaptive radiation of the griffon vultures. In: Wilbur SR, Jackson JA (eds) Vulture Biology and Management. University of California Press, Berkeley, pp 135-152

Houston DC, Meeb A, McGradyc M (2007) Why do condors and vultures eat junk?: the implications for conservation. J Raptor Res 41:235-238

Kelly NE, Sparks DW, DeVault LT, Rhodes OE Jr (2007) Diet of Black and Turkey Vultures in a Forested Landscape. Wilson J Ornithol 119:267-270

Koenig R (2006) Vulture research soars as the scavengers' numbers decline. Science 312:1591-1592

König C (1983) Interspecific and intraspecific competition for food among Old World vultures. In: Wilbur SR, Jackson JA (eds) Vulture Biology and Management. Univ of California Press, Berkeley, pp 153-171

Kruuk H (1967) Competition for food between vultures in East Africa. Ardea 55:171-193

Lambertucci SA, Trejo A, Di Martino S, Sánchez-Zapata JA, Donázar JA, Hiraldo F (2009) Spatial and temporal patterns in the diet of the Andean condor: ecological replacement of native fauna by exotic species. Anim Cons 12:338-345

Lemus JA, Blanco G, Grande J, Arroyo B, García-Montijano M, Martínez F (2008) Antibiotics threaten wildlife: circulating quinolone residues and disease in avian scavengers. PloS ONE 3:e1444. doi:10.1371/journal.pone.0001444

Margalida A (1997) Consumición de pequeños cadáveres por parte de buitres leonados (Gyps fulvus) en Cataluña (NE España). Butll Grup Cat Anell 14:55-57

Margalida A, Heredia R, Razin M, Hernández M (2008) Sources of variation in mortality of the Bearded vulture Gypaetus barbatus in Europe. Bird Cons Int 18:1-10

Margalida A, Bertran J, Heredia R (2009) Diet and food preferences of the endangered Bearded Vulture Gypaetus barbatus: a basis for their conservation. Ibis 135:235-243

McCullagh P, Nelder JA (1989) Generalized linear models. Chapman and Hall, London

McCullagh P, Searle SR (2000) Generalized linear and mixed models. Wiley-Interscience, New York

Mundy P, Butchart D, Ledger J, Piper S (1992) The vultures of Africa. Academic Press, San Diego 
Mysterud A (2000) Diet overlap among ruminants in Fennoscandia. Oecologia 124:130-137

Parra J, Tellería JL (2004) The increase in the Spanish population of Griffon Vulture Gyps fulvus during 1989-1999: effects of food and nest site availability. Bird Cons Int 14:33-41

Pyke GH, Pulliam HR, Charnov EL (1977) Optimal foraging: a selective review of theory and tests. Q Rev Biol 52:137-154

Schoener TW (1968) The Anolis lizards of Bimini: resource partitioning in a complex fauna. Ecology 49:704-726

Stephens DW, Brown JS, Ydenberg RC (2007) Foraging: behavior and ecology. University of Chicago Press, Chicago

Tella JL (2001) Action is needed now, or BSE crisis could wipe out endangered birds of prey. Nature 410:408

Tokeshi M (1999) Species coexistence, Ecological and evolutionary perspectives. Wiley-Blackwell, Malden
Travaini A, Donázar JA, Rodríguez A, Ceballos O, Funes M, Delibes M, Hiraldo F (1998) Use of European hare (Lepus europaeus) carcasses by an avian scavenging assemblage in Patagonia. J Zool Lond 246:175-181

Villafuerte R, Calvete C, Blanco JC, Lucientes J (1995) Incidence of viral hemorrhagic disease in wild rabbit populations in Spain. Mammalia 59:651-659

Wallace MP, Temple SA (1987) Competitive interactions within and between species in a guild of avian scavengers. Auk 104:290-295

Wauters LA, Gurnell J, Martinoli A, Tosi G (2002) Interspecific competition between native Eurasian red squirrels and alien grey squirrels: does resource partitioning occur? Behav Ecol Sociobiol 52:332-341

Wilson DS (1975) The adequacy of body size as a niche difference. Am Nat 109:769-784 